\title{
Circular Temporary Labour Migration: Reassessing Established Public Policies
}

\author{
Ricard Zapata-Barrero, ${ }^{1}$ Rocío Faúndez García, ${ }^{2}$ and Elena Sánchez-Montijano ${ }^{1,3}$ \\ ${ }^{1}$ GRITIM-UPF (Interdisciplinary Research Group on Immigration), Department of Political and Social Sciences, \\ Universitat Pompeu Fabra, 08005 Barcelona, Spain \\ ${ }^{2}$ Political Science and International Relations Department, Universidad Alberto Hurtado, 8340575 Santiago, Chile \\ ${ }^{3}$ Barcelona Centre for International Affairs (CIDOB), 08001 Barcelona, Spain
}

Correspondence should be addressed to Ricard Zapata-Barrero, ricard.zapata@upf.edu

Received 13 November 2011; Revised 16 March 2012; Accepted 2 May 2012

Academic Editor: Bridget Freisthler

Copyright (C) 2012 Ricard Zapata-Barrero et al. This is an open access article distributed under the Creative Commons Attribution License, which permits unrestricted use, distribution, and reproduction in any medium, provided the original work is properly cited.

\begin{abstract}
Circular Temporary Labour Migration (CTLM) is being promoted as an innovative and viable way of regulating the flow of labour migrants. Based on a specific empirical case study, we identify an unexpected outcome of CTLM programmes: the emergence of a new empirical migrant category, the circular labour migrant, which is as yet theoretically unnamed and lacks recognition by public institutions. We argue that, to date, there have been two historical phases of circular labour migration: one with total deregulation and another with partial regulation, involving private actors supported by public institutions. In a developed welfare state context, it would be normatively pertinent to expect a step towards a third phase, involving the institutionalization of this new trend in mobility by the formulation of a public policy. Current legal, political, social, and economic frameworks have to be reassessed in order to recognise the category of the circular labour migrant.
\end{abstract}

\section{Introduction}

In the search for new ways to channel human mobility, Circular Temporary Labour Migration (CTLM) has recently become a basic course of action promoted by relevant economic and political agents. Although the phenomenon of Temporary Labour Migration (TLM) originally emerged after the Second World War, a new type is now appearing: circular labour migration. Indeed, in the 1940s and 1950s, many workers from developing countries emigrated to the United States and Europe for temporary periods, in response to the needs for national reconstruction and the lack of lowskilled workers. However, the beginning of the twenty-first century saw a new boom in TLM programmes that share some traits with previous ones (economic sectors, skills level), but also have their own distinctive features. First, these new programmes are often managed by business actors who are directly involved in hiring. Second, and more importantly, there has been a tendency towards creating workers' programmes that are circular in nature, involving the same individuals year after year, with an annual return that is assumed rather than implied.

International organizations have pointed out the potential benefits of this new system of mobility. These virtues are said to be a result of the link between three development processes: the country of origin, the receiving country, and the temporary workers. It is precisely because of this "triple win" effect that different institutions promote it. Some examples of this include the EU pilot circular migration and mobility partnerships, as defined by the 2839th Council of General Affairs and External Relations, and the Commission Communication on Circular Migration and Mobility Partnerships between the European Union and Third Countries [1], which underlines the importance of closer cooperation with third countries in managing migration flows.

Based on a specific empirical case study of a CTLM project, organized by the largest agricultural business association in Catalonia (Spain), Unió de Pagesos, ${ }^{1}$ we closely examine the expected "triple win" result. This programme (which we refer to as "UPP"—Unió de Pagesos Programe) 
has been highlighted by several international organizations (OECD, EU, IOM) as an innovative way of regulating the flow of low-skilled labour migrants and preventing irregular migration towards Europe. However, the aspect we will highlight in this analysis is the project's unexpected impact on migrant rights, due to the lack of recognition of a new empirical migrant category: the circular labour migrant. This migrant differs from the traditional temporary worker in one fundamental respect: the same individual travels back and forth between countries year after year for a substantial period of time, during which he/she remains in what could be called a permanently temporary condition. This particular status is still theoretically unnamed, and lacks political and legal recognition by public institutions.

In this framework, we argue that to date there have been two historical phases of circular labour migration: one of total deregulation of migrant labour markets, and another of partial regulation carried out by private actors with public institutional support. In a developed welfare state context, it would be normatively pertinent to expect a step toward a third phase, involving the institutionalization of this new trend in mobility by the formulation of public policy which recognizes this new migrant category as a status: the circular labour migrant. To that end, current legal, political, social, and economic frameworks need to be reassessed.

This article contributes to the development of an empirically based institutional research agenda on circular labour migrants. Following an inductive path, it departs from the knowledge of the specific conditions faced by migrants involved in the new breed of programmes for the management of migration flows, and reaches conclusions of a normative nature.

The article is organized as follows. In Section 1, we look at how CTLM has been theorized. In Section 2, we focus on how temporary worker migration has evolved in Europe over the last three decades, with special emphasis on the Spanish case and on our study case, UPP. We then discuss the need to move on to a new stage, thereby ending the "invisibility of the circular labour migrant" by the formulation of a CTLM policy. This policy should be based on institutional recognition of the circular migrant status, in order to further protect migrants' rights. Finally, we present some conclusions that arise from the empirical analysis and the normative proposal that we advocate.

\section{Conceptualizing Temporary Migration and the Debate on Circularity}

At present, most Western countries have temporary worker programmes as a solution for labour shortage in certain sectors of the economy, and particularly those related to agriculture, construction, and tourism. Today, the majority of these programmes are circular in nature. According to the Global Commission on International Migration (GCIM) [2], the desired transition in the management of temporary workers is towards voluntary circular migration programmes, instead of guest worker programmes such as those of the post-war years.
The concept of circularity applied to temporary migration has been widely debated in the literature, with two basic points of view standing out. On the one hand, what is known as the restricted definition, which sees circular migration as less than one year's presence in a foreign country, repeated over time and for a short period. On the other hand, the extended definition refers to the return of migrants to the place of origin after a long period abroad, without implying seasonality or constant entry and exit.

To date, the bulk of the literature had taken the extended definition of circularity into account. However, this approach — as Constant and Zimmerman [3] pointed outfails to consider issues such as the length of time spent in each country, the worker's legal status, and the type of work undertaken during this time.

The majority of the literature has recently opted for more complex forms of the restricted definition ([3-5] etc.). This is the vision adhered to, for example, by the Migration Policy Institute (MPI), which defines circular migration as "a continuing, long-term, and fluid pattern of international mobility of people among countries that occupy what is now increasingly recognized as a single economic space" [6]. It is possible to identify different subcategories within this pattern: temporary/seasonal migration, nonseasonal lowwage labour, and the mobility of professionals, academics, and transnational entrepreneurs. In any event, according to the MPI, what distinguishes this "new circularity" of the twenty-first century from temporary migration itself is the combination of return and repetition [6]. It involves a movement that tends to be repetitive- a shift from the traditional idea of a finite circle, defined by departure and return. It is this feature which explains the uniqueness of this migratory dynamic, and it should also become the basis for establishing an appropriate public policy—as we argue below.

The majority of current definitions of circular migration have a strong prescriptive character [7] reflecting, amongst other things, the place that this category occupies in the contemporary debate on migrations and development [8]. Based on restricted visions, various international organizations have adopted standpoints on the advisability of this system of mobility, which would create an expected "triple win" situation. In 2005, the GCIM called on developed countries to promote circular migration, applying mechanisms to permit the easy and rapid movement of workers between countries of origin and destination [9].

Similarly, the International Organization for Migration (IOM) [10] highlights the benefits of temporary and circular migration for the different actors involved and for developed countries in particular. The European Commission's Communication on "Migration and Development" [11] and later its Communication on "Circular migration and mobility partnerships between European Union and third countries" [1] promote the exploration of ways to facilitate circular and temporary migration, "inviting to present detailed proposals on how to organize the diverse forms of legal movement between the EU and third countries" [1]. Finally, the Organization for Economic Cooperation and Development [12] highlights the circularity model as the most recommendable 
TABLE 1: Phases of temporary worker migration.

\begin{tabular}{|c|c|c|c|}
\hline & PHASE 1 1980s and 1990s* & $\begin{array}{l}\text { PHASE } 2 \text { End of the } 1990 \text { s-First } \\
\text { decade of } 2000\end{array}$ & PHASE 32011 onwards? \\
\hline Phase & Deregulation. & Deregulated liberalization. & $\begin{array}{l}\text { Institutional recognition in the form of } \\
\text { public policy. }\end{array}$ \\
\hline $\begin{array}{l}\text { Principal traits of } \\
\text { migration }\end{array}$ & $\begin{array}{l}\text { Irregular and temporary } \\
\text { migration managed by labour } \\
\text { market. Context encourages } \\
\text { irregular immigration. }\end{array}$ & $\begin{array}{l}\text { Regular migration. Move from } \\
\text { guest worker to temporary and } \\
\text { circular labour migration } \\
\text { managed by the labour market. }\end{array}$ & $\begin{array}{l}\text { Regular migration. Temporary labour } \\
\text { migration characterized by circularity } \\
\text { and managed by public sector. }\end{array}$ \\
\hline Type of intervention & $\begin{array}{l}\text { Little public policy } \\
\text { intervention in the irregular } \\
\text { labour market. }\end{array}$ & $\begin{array}{l}\text { Management of flows. Protection } \\
\text { of some rights (contracts, } \\
\text { housing, education, healthcare, } \\
\text { etc). Emergence of programmes, } \\
\text { subsidies and grants. }\end{array}$ & $\begin{array}{l}\text { Public or mixed management of } \\
\text { temporary work and recruitment. } \\
\text { Improved regulation of private activity. } \\
\text { Protection of wider labour, union, and } \\
\text { social rights. }\end{array}$ \\
\hline $\begin{array}{l}\text { Recognition of circular } \\
\text { temporary labour status }\end{array}$ & No recognition. & Partial recognition as worker. & $\begin{array}{l}\text { Recognition of circular migrant worker } \\
\text { with rights under public policy. }\end{array}$ \\
\hline
\end{tabular}

Source: own research.

* This study had an actor-network approach, and was carried out using qualitative techniques; namely, 20 interviews and 5 focus groups with workers, employers, local authorities, civil society organizations, and other business associations in the region. For more information on the methodology, see Zapata et al. 2009.

route for the development of many origin countries. The premise in all these recommendations is clear; circularity is not possible with legal restrictions and without governmental support. Actually, it always implies a governmental commitment to this type of migration.

Despite the international recognition of circular migration in the literature and by institutions, circular migrants themselves have received little political or academic attention and continue to experience problems in the institutionalization of their rights. Indeed, while the literature attempts to construct an agreed conceptual framework that fits the new reality of circular migration at the beginning of the twenty first century, there have been no adjustments to the categorization of the people who form part of these new processes. This lack of conceptual recognition reflects the legal and political invisibility of these migrants. Despite the efforts made to regulate their situation, current frameworks continue to operate using traditional categorizations and, therefore, remain incapable of taking the complexity, fluidity, and potential of this new migration dynamic into account. The basic aim of this article is to justify the need for a new phase in the contemporary debate on circularity, ranging from the confirmation of this de facto dynamic to its consolidation as a category that may be a subject of public policy and of recognition of rights.

\section{From Deregulation to Regulated Liberalization}

The boom in CTLM during the last two decades has followed a course of increased rationalisation and institutionalisation. In this section, we shall describe two phases of temporary labour migration, taking into account Spain, in the European context, and the UPP. The first phase, during the 1990s, was one of irregular labour migration, which entailed a lack of political institutional intervention and the complete absence of migrants' rights. The second-and current-phase, which began in the late 1990s, is one of temporary migration under a system of regulated liberalization. Based on the obvious differences between these two models, we argue (in Section 4) for the need to move towards a new phase: institutional recognition of the circular labour migrant and, consequently, the protection of his/her rights (see Table 1).

\subsection{Phase 1: The Recent Past. Deregulation of Temporary} Migration During the 1990s. Until the 1990s, temporary migration (especially when linked to agriculture) involved the spontaneous movement of nationals within their own borders in search of work at specific times of the year. In the Spanish case, with territorial cohesion, economic growth, and, finally, entry into the European Community in 1985, this labour force began to be replaced by immigrant workers.

Despite the political restrictions imposed on low-skilled immigrants during the 1990s, labour market needs in the context of accelerated globalization encouraged the "informal" recruitment of irregular immigrants [2]. The disparity between restrictive policies and real labour market needs led to the recruitment of irregular immigrants on the one hand, and the reintroduction of guest worker programmes that had been suspended in the 1970s, on the other. These temporary worker programmes, which were reinitiated at the beginning of the 1990s, were based on the opportunities that foreign and border policies offered migrants to participate in temporary contracts. In Spain, the recruitment of temporary workers in origin did not begin until the late 1990s. Although a "contingents"2 system had been in place since 1993 [13], it was poorly developed and had little take-up.

In Catalonia, seasonal labour needs in agriculture due to rural-urban migration were firstly met by workers from the southern Spain (Andalusia/Extremadura) during the 1960s. They were then replaced by students who worked during the 
summer in the 1970s and 1980s and, once again, by workers from the rural south of Spain during the 1980s.

Finally, in the 1990s, entrepreneurs continued to recruit Spanish migrants, but increasingly resorted to irregular international immigrants. This was a result of the rural exodus of the 1990s, due to the growth of urban areas and to the native population's lack of interest in this type of work because of the low salaries, low skills required, harsh physical conditions, and its temporary nature.

The benefits were sufficient to outweigh the legal repercussions (fines or imprisonment) that recruiting irregular immigrants entailed for entrepreneurs. There were, therefore, two dynamics linked within one market space. First, irregular immigrants living in Spain were the only workers willing to work in certain sectors of the labour market. Entrepreneurs therefore looked to them when providing labour. Secondly, workplace inspections by public administrations were relatively lax at that time. ${ }^{3}$ The coexistence of these two situations allowed immigrants to rely for a long time on the opportunities that the irregular Spanish labour market offered [14].

The majority of irregular immigrants and, later on, regular temporary workers took up positions in agriculture, followed by the service and construction sectors. In most cases, job offers took the form of verbal agreements for temporary, low-skilled, and low-paid jobs [15].

It was not until early 2001 that the situation of irregular immigrants came to national attention. ${ }^{4}$ This was triggered by various media events, including the death of a group of irregular immigrants in southern Spain. ${ }^{5}$ One of the first responses was an ambiguous outbreak of social alarm regarding two issues: the inefficiency of government controls over workplace inspections, as well as the tolerance of the government, entrepreneurs, and unions to this widespread practice [16]. The political reaction was to regulate the labour market through bilateral agreements. The Spanish and Ecuadorean governments signed the first bilateral agreement on flows control in late 2001. Subsequent agreements were signed with Colombia, the Dominican Republic, and Morocco. These agreements had the desired effect of reducing irregular contracts and regulating the recruitment of workers directly in origin countries and, thus, began a new phase. Our case study, the UPP, is part of this new phase and has become essential in providing temporary workers for Catalan agriculture.

\subsection{Phase 2: The Current Situation. Regulated Liberalization} in the First Decade of the Twenty-First Century. Today, there are seasonal temporary worker programmes (both circular and noncircular) in Germany, the Netherlands, Norway, Ireland, Belgium, Sweden, Greece, Italy, Spain, and the United Kingdom. In this new general context, there has been a huge growth in the number of temporary workers taking up the opportunity to work legally in high-income European countries [17].

These initiatives are considered an improvement on previous ones. Through careful design, they are expected to avoid the errors of post-war temporary worker programmes, specifically in terms of temporariness [2]. Current programmes are on a much smaller scale; they are focused on specific sectors, territories, and industries (including, yet again, agriculture, construction, and tourism). They tend to adjust to preestablished quotas, as a function of labour market needs, with recruitment taking place in origin countries, through embassies and consulates or by intermediaries that are strictly supervised in some countries-and less so in others [18].

This new model relies on two basic features: the guarantee of the permanent temporary nature of migration, with circularity acting as a key element, and the appearance of economic actors as managers of the migration process.

In fact, the mechanism of circularity has not only become a distinctive feature of the new batch of programmes, but has also turned out to be one of the most efficient mechanisms protecting the temporary nature of migration. The incentive of returning the following year, under reasonably good conditions and with a certain level of income guaranteed, becomes a deterrent for each individual worker against permanent migration-regular or irregular.

Another distinctive feature of current programmes is that they are designed and managed by actors from the private sector-and occasionally from the third sector. These actors have also taken a leading role in influencing policymakers, in order to establish the legislative framework needed [19].

In Spain, during the 1990s, previous experiences of temporary migration began to give way to guest worker programmes. These in turn laid the foundations for the emergence of a new generation of circular programmes by the end of the decade; one of these was the UPP in 1999. As a result, a period of very restrictive policies for granting work permits to low-skilled workers, coexisting with totally deregulated labour market, made way for the establishment of procedures that permitted channelling flows within a legal framework. This new consensus aimed at the regulated liberalization of the movement of workers, making up for the shortage of native workforce [18]. Seasonal agricultural programmes are a great example of the attempts made to reconcile a flexible labour market (needed by a sector that competes globally, and requires a large number of low-skilled workers, in a temporary and cyclical manner), with regulation (the prevention of irregular migration and definitive settling of unqualified workers). ${ }^{6}$

In Spain, as in the rest of Europe, this was possible due to the existence of a well-defined institutional framework, which was actually tailor-made to meet the challenges faced. Bilateral agreements have been the building blocks for organizing labour migration flows in general and the migration of low-skilled temporary workers in particular. Various mechanisms exist, each with its own criteria for admission and norms for regulating the length of stay. On one hand, there are framework agreements between governments, establishing the parameters with which all actors involved must comply. ${ }^{7}$ However, there is also a wide range of more specific agreements between governments (generally of countries of origin) and regional or local authorities (e.g., the Spanish Autonomous Communities). Finally, countless agreements have been established between 
governments (of countries of origin) and private recruitment agencies, and even directly with workers' unions or business associations.

This plural institutional framework clearly reflects the twofold objective of liberalization and regulation. More specific bilateral agreements meet the needs of a flexible and increasingly transnational labour market, with actors in destination countries becoming directly responsible for negotiating the optimum conditions to increase productivity in their respective sectors. The result is an uneven set of tailor-made, highly decentralized bilateral agreements at a nongovernmental or semigovernmental level and programmes mainly implemented by the private sector. State control focuses on selecting the countries outside the EU with which to establish framework agreements and controlling the entrance and permanency mechanisms. There should be no doubt that although the resulting situations may be more liberal than those established by the strict GATS $^{8}$ agreement [17], there is no relaxation of border controls, but rather an increased capacity for effective regulation of access: who enters, for what reason and for how long. In fact, foreign policy considerations play an important role in defining with which countries framework agreements are to be established, allowing for specific agreements to be developed afterwards. ${ }^{9}$ As a result, Spain has strategies for legally admitting temporary workers from countries such as Morocco (similar to Italy with Albanians), in exchange for the readmission of irregular immigrants and cooperation on reducing irregular migration $[17,20]$.

The UPP is an excellent example of this new generation of programmes. It is a formula for the private management of circular, temporary labour migration and has been used by the Catalonian agricultural sector since 1999. The Programme is managed by the Unió de Pagesos, a farmer's association that includes 70 per cent of all Catalan agricultural businesses.

In response to a dramatic shortage of manpower during the critical fruit picking period, the Unió de Pagesos has established a recruitment system in origin countries, bringing temporary workers to work in its members' fields. In order to do so, it has used the framework agreements on foreign workers' "contingents" or quotas.

The Regulation in Organic Law 4/2000, passed by Royal Decree 2393/2004, on 30 December, establishes quota conditions and authorises temporary residence and employment for a set period of time. It designates the offers of temporary work to countries that have signed bilateral agreements with Spain and limits the length of temporary contracts to nine months, within a 12 -month period. It also obliges employers to provide adequate housing for workers during their stay, as well as organising travel logistics to and within Spain. In turn, the worker must agree to return to his/her country of origin once the work permit expires. The quota is adjusted annually and approved by the Government. The workers are recruited in origin countries, based on the offers presented by entrepreneurs. There are also provisions for entrepreneurs to participate in the selection process in the country of origin, if they wish. Unió de Pagesos invokes this clause for the recruitment of workers in the country of origin. This has enabled it to open offices in Colombia and to recruit workers directly.

Unió de Pagesos has not only been able to adequately interpret and take advantage of the existing regulatory framework. It has also acted as a lobbyist at all relevant legislative levels (state, autonomous, and provincial) and has directly endorsed an agreement with the Colombian Ministry of the Interior and Justice. For this reason, it may be considered a codesigner of the current institutional framework. The UPP, which began with the recruitment of 35 Colombian workers, allows workers to come repeatedly, for several months of the year (between three and nine), to work in the different agricultural campaigns in Catalonia, the Valencia Region, and the Balearic Islands, subsequently returning to their country of origin, and returning to Spain the following year. In 2008, 3,211 workers (mainly Colombians but also Moroccans) were recruited in their country of origin.

Although CTLM has not always succeeded in preventing permanent migration, the UPP seems to meet promising conditions. Compared to other CTLM practices in Spain, the desertion level is very low. As of 2007, only six per cent of its temporary workers had remained irregularly in the receiving country (this percentage is half that of other CTLM practices) [21]. This has been confirmed in interviews with temporary workers, in which very few showed any interest in undertaking permanent immigration. This attitude could possibly be linked to the socioeconomic profile of the workers that Unió de Pagesos favours, that is, workers that are very poor in their national contexts. ${ }^{10}$ They are, therefore, not of the same social extraction as irregular immigrants (which tend to be poor but not extremely so). The possibility of being recruited the following year also acts as a deterrent to desertion.

As for the circular labour migrant himself/herself, as part of the so-called "triple win," situation it is important to note that participation in the programme leads to a significant improvement in quality of life in economic terms. According to interviewees, remittances mean children can continue primary and secondary education and, often, even gain access to university, which results in very positive social (generational) mobility for the family and the community. Remittances are also used to pay off debts, incurred in undertaking the trip or due to previous commitments. However, the biggest investment made by workers during their first year is to improve living conditions (purchasing a house, or making improvements to an existing house). Later, after some years in the programme, some workers consider setting up their own productive projects, as they have been able to accumulate a significant amount of capital compared to their usual income.

Furthermore, taking into account the entire set of temporary agricultural migrants in the region, the transition from irregular to regular migration has had an important impact on the situation of workers. There has been a shift from a situation of complete vulnerability to abusive working conditions, to the recognition of a basic set of social and labour rights. In principle, the UPP provides various basic guarantees. First, salaries are equal to those of native workers, and workers are protected from the risk of entering forced 
labour. ${ }^{11}$ Second, workers are entitled to social security during their stay, to housing that reaches minimum standards, to an air fare paid for by their employer, to fixed working hours and a day of rest, to holidays, and to union representation. However, as we will see, under close examination this basic "package" of rights has various shortcomings.

Although the regulatory role of the state that receives temporary workers focuses mainly on controlling their entry and exit, it also extends to the area of social and working conditions, as can be seen in the UPP. The result is a situation radically different from the previous phase. Nevertheless, the difference between temporary workers' rights and the rights of permanent immigrants persists; indeed, it seems to play an important role in the delicate system of incentives and punishments managing circular migration [18].

\section{The Need to Move towards Public Policy on CTLM}

The transition from a deregulated phase of temporary migration to the current situation, with circular programmes channelling the mobility of these workers, has had a highly positive impact on all the actors involved: the country of origin, the country of destination, and the circular migrant. However, there is still significant room for improvement of the existing institutional mechanisms.

To date, the literature making recommendations for the improvement of programmes $([6,9,10,17,20,22,23]$ etc.) has focused on two main issues: how to strengthen the contribution of circular migration to the development of countries of origin, and how to promote and protect the temporary and circular nature of this type of migration. The focus has, therefore, been placed on the origin and destination countries. Instead, we suggest focusing attention on the third actor in the so-called "triple win" scenario. From a normative point of view, the figure of the circular labour migrant poses significant challenges and highlights some outstanding issues.

As mentioned above, a decrease in irregular migration has implied an improvement in the labour conditions of temporary workers. However, the recognition of circular migrants' rights is subject to some limitations inherent in their condition and their institutional invisibility.

This is the starting point for our argument in favour of the introduction of a policy for circular labour migrants. Such a policy should clearly define the legal frameworks that liberal-democratic Welfare States use to categorize this type of migrant. This is a fundamental step for receiving countries to effectively face the questions raised by new migratory issues, and consistent with their own principles of justice. Circular migration is already gathering attention as a policy object within the EU framework, due to its perceived potential to satisfy labour demand, whilst ensuring return and providing the "triple win" scenario [24]. However, the current EU legislation to support circular migration is only partially regulated (Directive 2009/50/EC, Directive 2004/114, and the proposed Directives 2010/0210 or 2010/0209) and provides a broad context for different national approaches, leaving ample scope for the member states to adopt their own rules.

Focusing on the UPP, we first attempt to demonstrate how the circular labour migrant continues to be a difficult category to pin down in conventional frameworks. This in turn favours weak public intervention in current labour migration programmes. After discussing this, we then illustrate our findings on the current situations that involve the infringement, or risk of infringement, of the rights of circular migrants.

4.1. The "Invisibility" of the circular labour migrant. As mentioned above, the recent literature on circular migration has little to say about the circular migrant; and when it mentions them, it rarely employs the language of rights, and nor does it consider the circular labour migrant as a new status. There appears to be a consensus among the academic community and international organizations that new programmes are so superior to the previous situation of total deregulation that the rights of workers are no longer considered a problematic issue. Temporary programmes that continue to suffer problems with the recognition and enforcement of rights are considered to be those carried out in undeveloped and/or nondemocratic countries. Unfortunately, these assumptions have meant that not enough attention has been placed on the shortcomings that, as we shall see, still persist, even in particularly successful and well-managed programmes like the UPP. It is true that they do not involve problems as flagrant as those encountered by the irregular worker or those prevalent in countries with authoritarian regimes or fewer resources. However, the kind of labour relation emerging in programmes like the one analyzed here displays a sufficient component of rights vulnerability for the issue to be brought to the attention of union organizations, the administrations, and the state in the destination country.

In this section, we shall delve deeper into three concurrent factors, which have contributed to maintaining the fragile situation of circular labour migrants, leaving them in the hands of economic forces without any institutional counterweights: (a) the trade-off between rights and economic gains; (b) the inadequacy of international systems for the protection of rights; (c) the blindness of the State in relation to the circular temporary migrant. Taken together, these factors are a virtual condition of invisibility of the circular migrant for actors outside the private sector.

(a) The Trade-Off between Rights and Economic Gains. It seems to have become common sense to accept that these new formulas "will necessarily involve some trade-off between the economic gains (...) and restrictions of some of the individual rights of migrants while employed abroad" [22]. The assumption is that for their continued existence, the two basic features of these programmes (temporariness and circularity) require migrants to enjoy only a limited level of given rights. Two clear examples are the right to freedom of movement in the labour market and the right to family reunification. This is legitimate, it is argued, not only because of the economic benefits for the destination 
country but also for migrants, given the high incomes that can be earned during their stay abroad. ${ }^{12}$ In addition, the workers themselves are often willing to give up their rights in exchange for earning a higher salary during their stay. Ultimately, rights appear to be just another instrument to be weighed up when designing a programme: they will be ignored or enforced depending on the needs of economic competitiveness and on the delicate balance that secures temporariness and circularity. As in the past, workers' rights become material for negotiation; yet again, they become contingent. ${ }^{13}$

(b) The Misalignment with International Systems for the Protection of Rights. If national and international normative frameworks have proved inadequate in regulating the phenomenon of migration in general (see [25]), they find temporary migrants even more elusive. Even international rights organisations have problems with this "anomalous" category. In fact, the system established during the twentieth century for the protection of migrant workers' rights barely covers a very small group [20]. The two International Labour Office (ILO) Conventions dedicated specifically to migrant workers (No. 97, 1949 and No. 143, 1975) were formulated with the model of permanent migration in mind, and thus exclude temporary migrants from the rights listed. ${ }^{14}$ Some efforts have been made to fill the gaps in the protection of migrants' rights only recently. Two examples are the International Convention on the Protection of the Rights of All Migrant Workers and their Families, passed by the UN General Assembly in 1990, and the ILO Report (2004) "Towards a Fair Deal for Migrant Workers in a Global Economy". The latter declares that temporary migrant workers enjoy the protection of fundamental principles and rights, and are entitled to benefit from the provisions in Convention No. 97, referring to equal treatment. It also establishes that temporary migrants are not included from the provisions made by Convention No. 143 [18]. However, there has not been a firm and indisputable incorporation of temporary migrants into the regulatory system consisting of these instruments for the protection of rights. As circular migrants are part of the latest brand of temporary workers and remain as such for extended periods of time, they are particularly affected by this omission.

(c) Invisibility in the Eyes of the State. Circular migrants are "invisible" to the eyes of destination states. ${ }^{15}$ At the international level, the current categorization distinguishes between the "immigrant" (i.e., a person of foreign origin who has moved to another country specifically for work, and who plans to engage in his/her personal or family life there), and the "migrant" (a person in the process of movement from his/her country to another). According to the IOM [26], immigrant status is the "status that a migrant is accorded under the immigration law of the host country" and it is this (not migrant status) that guarantees his/her institutional recognition and protection under the law in the destination state (e.g., through work or residence permits that are the basis for the acquisition of certain rights). In fact, until now, the "migrant" condition has not been thought of as a status, as it is considered a transitory process. However, the phenomenon of circular migration has changed this situation de facto, making the vulnerability already suffered by common temporary workers more persistent.

Indeed, in destination countries, temporary migrant workers remain outside ordinary legal parameters, as they are only afforded selected and partial rights, in contrast to native and permanent immigrants. ${ }^{16}$ Neither do they benefit from the policies and programmes directed at the immigrant community, as they do not form a part of it. Even at civil society level, they do not participate in immigrants associations or in workers' unions, as we shall see.

Lastly, although international migration statistics do record the movement of temporary migrants ${ }^{17}$ at the destination state level, these movements are not adequately measured, either by census data ${ }^{18}$ or by the kind of administrative data used to measure the entry and exit of migrants, tourists, international students, business visitors, and so forth [19]. Circular migrants are a new type of temporary worker that is particularly hard to measure. As Agunias and Newland [23] point out, in a broader sense,

"the nature of the transnational movement of
people requires data to be collected from countries
of origin and countries of destination, which in
turn calls for coordination of such data from
various sources. As already noted above and worth
repeating, the permanent settlement migration
paradigm still defines our data collection systems.
Thus, no system is yet in place to capture ade-
quately the contemporary movement of people."

It is certainly difficult for something that cannot be measured or counted to exist in institutional terms, and becoming a matter of public policy is even more so. There cannot be a better governance of this type of migration-as organisations such as the GCIM and the IOM demand-if we cannot grasp the very phenomenon we are talking about.

In short, as long as temporary-and therefore, circularmigrants continue to constitute a "blind spot" for both states and the international system for the protection of workers' rights, it is unrealistic to expect programme managers to systematically recognize workers' rights. This lack of recognition generates a lax normative environment, where rights that do not substantially affect the rules of the game are respected, while rights that could prove potentially conflictive are respected either minimally or not at all (on paper or in practice).

4.2. Problems with the Recognition and Protection of Rights. In order to present the shortcomings we have found in the UPP, we will make a distinction between legal, social, and labour conditions. In this section, we have included both the nonrecognition of rights (on the formal level) and the infringement of rights (informal practices that systematically breach the formally established provisions for the protection of rights). 
(a) Legal Conditions. We begin by describing some characteristics of the legal conditions of circular migrants. As we will see, their current situation is not conducive towards them claiming any type of rights, thereby aggravating the problems related to the social and working conditions that we refer to hereinafter.

First, these migrants' legal status depends exclusively and directly on their employers [21]:19 the work visas they hold, tied to specific contracts, do not grant them autonomy. This restricts their right to move freely within the Spanish labour market, limiting their opportunities to find better working conditions by changing their job, and facilitates exploitative situations. An immigrant remarked:

\section{"I understand that the contract is a commitment and if you do not fulfil it then you are responsible. But if they do not fulfil their commitment to you, what happens then? ' If I want to leave, I have to pay for breaking the contract; but if Unió de Pagesos does not fulfil its commitments it doesn't have to pay anything" (Interview 6, July 2007).}

International experience has shown that the dependence on one job and one specific employer conspires against workers' capacity to organize themselves and make demands on their employers, due to the fear of losing their visas and having to leave the country, or even being placed on a "black list" and not being "selected" to return the following year [20]. As the Global Forum on Migration and Development (GFMD) [17] and the GCIM [22] propose, although the movement between sectors is difficult to implement in circular programmes, mobility between employers in the same sector should be authorised.

Second, Spain's legislative framework envisages the possibility of granting permanent residency after four years of a temporary visa and under contract from an employer. When interviewed, some migrants expressed interest in this option; in fact it had been used as an incentive during their recruitment. However, evidence suggests that this does not happen, at least not in significant numbers. Farmers prefer circular migrants to permanent immigrants, and there are no incentives encouraging them to end circularity by offering indefinite contracts, even though the legislation authorizes this. Although the right is formally established, ${ }^{20}$ in practice it is not applied. The only option for workers who wish to remain in the destination country is to become irregular immigrants.

Finally, circular migrants are not entitled to the right of family reunification (a situation common to the majority of temporary migrants around the world) [18].

(b) Social Conditions. Although there have been significant improvements in migrants' social conditions with CTLM programmes (particularly in developed countries), certain worrying conditions persist.

First, although workers are formally registered in the social security system at the beginning of each work season, they do not enjoy all the guarantees associated with this. They are left in an anomalous situation of selective participation in the existing benefits. Ultimately, the protection provided by social security becomes a further source of inequality between circular migrant workers and permanent, national, and immigrant workers.

For example, since 2009, temporary workers in Spain have been exempt from paying unemployment contributions. This measure is consistent with the tendency in temporary programmes to transfer unemployment costs to the countries of origin [27].

In addition, although the portability of pensions is considered a fundamental aspect to be guaranteed in this kind of programme [28], temporary workers in Spain are not obliged to make contributions to government pension schemes. For circular migrants, the repeated rotation for various months of the year, and over many years, will thus imply a huge gap in pension previsions. This puts the future pension funds of these workers in serious jeopardy, considering they already come from countries with deficient pension schemes, many of which have been recently privatised and liberalised.

Social security registration guarantees access to healthcare in the Spanish case. Nevertheless, we have found that this right is not being effectively implemented: workers deliberately avoid visiting the doctor when they are ill and only go after suffering accidents in the workplace. Again, this is because they are not entitled to yet another basic right of the social security- the right to take sick leave. This means that days not worked go unpaid. Given the fact that they have fixed expenses associated with their stay abroad (food, personal items, and accommodation) and wish to maximise their earning during their stay in Spain, there are strong deterrents against using the healthcare system.

Finally, although migrant housing officially meets a series of predefined standards, in practice some of these dwellings leave a lot to be desired. Overcrowding, lack of space for recreational activities in collective housing, insufficient equipment for the number of habitants in each accommodation, poor ventilation, and housing located on the outskirts of urban areas are a few of the most common problems. One worker says:
“(...) I know colleagues who have very poor housing conditions: how can they bring workers to live like that? They (the employers) are asking that you coexist (with others workers), have good behaviour and also deal with the emotional instability; but in these conditions it is difficult to know how. I know rooms of 2 by 3 meteres, they are containers, not rooms, and there are 6 workers living together... Kitchens are for 35 people; there are only 3 stoves, one refrigerator, and one washing machine. There are places that are in very bad conditions" (Interview 2, July 2007).

Although this situation seems to be the exception and not the rule, it poses a question about the level of monitoring of living conditions currently in force.

(c) Working Conditions. Although circular agricultural workers are formally part of the same collective bargaining agreement as nationals (Agricultural Collective Bargaining Agreement of Catalonia and/or provincial agreements), their 
working conditions tend to be worse than those of nativesalthough not to the extreme extent recorded in some developing countries, where discrimination may even be established by legislation [18]. The issue instead is one of unequal treatment occurring on an everyday basis.

As Martin [20] has pointed out, seasonal temporary programmes have become true "litmus tests" for the effectiveness of measures for the protection of workers in industrialized countries. As these workers are in the destination country for only a limited period of time, with intense work schedules and dispersed around, often, remote rural areas and in private houses, it is particularly difficult for unions or social and labour representatives to inform them about their rights. In addition, as mentioned above, there are aspects to their visas, and to circularity itself, which deter workers from reporting mistreatment and attempting to obtain better working conditions.

This series of factors (geographical dispersion, intense rhythm of work, visas dependent on the employer) and particularly the uncertainty regarding future recruitment means that the right to unionize or become member of a workers' union is rarely put into practice.

Another problem for circular workers is that even though they have signed fixed-term contracts, there is no guarantee of continuous work during that period. Prolonged inactivity is frequent, ${ }^{21}$ due to the weather (rain, hail, etc.), delays between the end of one campaign and the beginning of another, or simply due to a lack of work (surplus labour compared to the amount of work available at that point in time). Considering that there is no basic salary, these periods without work have a very negative economic impact on the migrants. According to one of them:

\section{"We work and fulfil the contract, but they cannot guarantee the work for the months that we are here." "Then I would ask that they guarantee at least $80 \%$ or $90 \%$ of the work" (Interview 3, July 2007).}

In addition, what becomes apparent is the asymmetrical relationship between the two parties involved in the contract, especially when with regard to their capacity to make demands when a contract clause is breached.

This situation is further aggravated by the fact that workers do not have access to all the information about contracts, living conditions during their stay and prevailing regulations beforehand. In addition, this labour relationship, which is by definition asymmetrical, is not intermediated by any regulatory bodies - in stark contrast to a similar programme with Guatemalan circular workers in Canada, where there is a permanent monitoring by employers, IOM, and the Government of Guatemala [29].

Lastly, as mentioned above, there are no certainties either about the annual continuity of contracts or about the criteria behind these decisions. Workers travel, year after year, never knowing whether they will be "chosen" for future periods. Decisions on circularity are, on the one side, entirely in the hands of the employer (which operates as an important disciplining mechanism), and on the other, in the hands of intermediaries in the countries of origin. Furthermore, the workers are recruited through links that have some features of patronage (both in the relationship between intermediaries and job candidates, and in the relationship between Unió de Pagesos and intermediaries). When all is said and done, the perception of those involved is that the contract depends on arbitrary factors: it is a "migration lottery" [21] that generates serious doubts about the equality of the selection process and the real criteria used to orientate it.

\section{Conclusions: A Basis for Entering Phase 3, Institutional Recognition in the Form of Public Policy, from 2010 onwards?}

For liberal democratic states such as Spain, which also act as welfare states for their citizens, the situation that we have described presents important normative problems. As Ruhs [22] points out, there are currently two ways of responding to the issue of whether the restrictions of circular immigrants' rights required for the success of these CTLM programmes can be justified and promoted as desirable immigration policy measures in liberal democracies. The first response is deontological in nature, and depends on the ethical framework considered optimum for evaluating public policy. The second kind of response is consequentialist: CTLM has proven to be the best alternative for managing the flow of low-skilled workers into countries with labour shortages, and superior in practice to irregular, permanent, or other types of temporary migration. Ultimately, we are faced with the "numbers versus rights dilemma," also put forward by Ruhs [30]: if all migrants were legal and received the same benefits as local workers, there would be a risk of entrepreneurs seeking less workers in the country of origin as these workers will have lost their advantage within the global labour market. The question would be whether we want more circular temporary workers or better conditions for them. "The logic motivating migration is difference, while the logic of protection seeks equality. There is no easy way to resolve this numbers-rights dilemma" [20]. Until now, albeit perhaps by omission, Spain and the majority of EU countries are responding in the latter way.

Admittedly, CTLM programmes would not prosper if they were too bureaucratic, rigid, costly, or slow in responding to the needs of employers and changing market conditions. Newland et al. [6] remind us of how dynamic labour markets are:

\section{"by the time central governments authorities rec- ognize and certify labour needs, employers satisfy requirements for trying to recruit already resident workers, and governments authorize employers to hire foreign workers, labour markets are likely to have shifted."}

This, in part, explains why programmes such as the UPP have emerged as a result of private initiative and are managed by those directly involved.

Furthermore, the tendency in CTLM programmes has been to "trust the employer" [20]. Entrepreneurs and their 
associations have increasingly been given more decisionmaking power in relation to the admissions, transport, and assignment of work to temporary workers. ${ }^{22}$ As we have already seen, they have even been granted the capacity to sign bilateral agreements with governments in origin countries. Our study case is a clear example of this. Ultimately, despite the apparent diversity of agents involved (NGO's in origin, Fundació Pagesos Solidaris ${ }^{23}$ and individual employers), only one institution (the Unió de Pagesos) is responsible for the recruitment, transport, and contracting of workers. It is the Unio de Pagesos itself, rather than the state or the regional government, which signed the agreement with the Colombian Interior and Justice Ministry establishing these programmes.

According to the literature, the unequal treatment of circular and, in general, temporary migrants, has taken particularly severe forms in countries where the organization of migration is left in the hands of job brokers, intermediaries, or contractors and where the work of union institutions is weak or illegal [18]. Returning to the deontological approach, we believe that it is fundamental to pose certain questions: how are we to act in order to widen the gap between such situations of flagrant rights infringements and the de facto violation of rights that persist in current circular programmes in democratic countries with the rule of law? What are the policy instruments available for states to reinforce the regulation of these programmes and protect the rights of circular migrant workers? When it comes to migratory flows and international relations, which roles may legitimately be transferred to private agents and which should remain in the hands of the state? What alliances can be established with entrepreneurs, international organizations, and unions in order to increase the level of transparency and accountability of CTLM programmes? What adjustments do organizations such as the Labour Inspectorate, the Social Security system, or the National Statistics Institute need to make in order to deal with the challenges posed by the category of circular labour migrants with increased effectiveness?

All of these questions should be part of the debate on a public policy for circular labour migration. As mentioned above, the GCIM defines the current programmes as an effort to replace guest worker programmes that permitted exploitation, with mutually beneficial systems of voluntary circular migration. However, this agenda goes beyond the capacities of programmes as such. For it to be carried out, there is a need for

\section{a set of appropriate government policies designed to secure equal treatment of migrant workers while abroad, enforce sanctions against both employers and migrant workers who violate the terms of the programmes, encourage migrants to return home, and assist in their reintegration [9].}

Alongside arguing here in favour of a third phase of circular temporary migration in the context of the welfare state, there are also some more basic assumptions that still have yet to be questioned. New circular programmes are based on the unverified hypothesis that circularity itself implies benefits for all those involved. Both international organizations and the academic world are supporting the circularity of temporary migration under the "triple win" assumption, often with little knowledge of the actual effects and consequences for those involved. While we have mentioned some of the problems migrants face in terms of their rights, it is equally true that circularity also implies potentially negative consequences for the two other actors: the countries of origin and destination. ${ }^{24}$ It would be extremely hasty to reach the conclusion that with circularity, temporary worker programmes have been elevated to a new and better phase in ethical and practical terms. If we take into account the fact that the oldest CTLM programmes have only been running for ten years, it becomes apparent that a lot of empirical research remains to be done before we can confirm or reject this assumption.

\section{Acknowledgments}

This article is based on the study "Temporary and circular labour migration (TCLM) between Colombia and Spain: a model for consolidation and replication", funded by the IOM and the AENEAS Programme. A former version of this article was presented at the 5th ECPR General Conference, Potsdam (10-12 September 2009). We wish to express our thanks for all the comments received during the writing process, and especially to our colleague Anthony Gilliland, and colleagues from GRITIM-UPF seminar series.

\section{Endnotes}

1. This study had an actor-network approach, and was carried out using qualitative techniques; namely, 20 interviews and 5 focus groups with workers, employers, local authorities, civil society organizations, and other business associations in the region. For more information on the methodology, see Zapata-Barrero et al. [31].

2. "Contingents" are specific offers that governments make for contracting temporary workers abroad, for specific tasks, within the general normative framework that regulates the movement of individuals from non-EU member states. The objective is to guarantee that labour market needs are covered when native workers cannot cover them. The job offers managed by "contingents" are aimed at countries with which Spain has signed flow regulation agreements. The first contingents were focused on two main labour areas: housemaids and agricultural workers.

3. In agreement with Portes and Haller [32], we must not forget that irregular employment leads to a series of positive effects for both the employer and the State. Employers benefit from low costs and highly flexible labour, and the State enjoys a reduction in the cost of production, with repercussions for the rest of society.

4. Although the fight against irregular immigration gained strength at the beginning of the twenty-first century, some attempts were made during the 1990s, with poor 
results. The main actions taken were extraordinary regularization, the restructuring and creation of public agencies and action plans, and the creation of annual quotas or contingents [13].

5. On January 3, 2001, a group of twelve irregular immigrants from Ecuador were killed on their way to work in the fields in Lorca, Murcia. A train crushed the van in which they were travelling. See El País, 04/01/2001, "Mueren en un paso a nivel 12 inmigrantes que viajaban hacinados en una furgoneta en Murcia" and El País, 04/01/2001, "Los ecuatorianos muertos trabajaban para un empresario condenado por explotación".

6. In fact, these are the same objectives that orientate all labour immigration policies in developed countries today. Points systems, such as the one introduced as a part of the reform of the British immigration model, are the most explicit institutional application of this two-pronged framework. In Great Britain, since March 2006, points have been assigned to migrants on the basis of "attributes" (that predict the migrant's success in the labour market) and "control factors" (that predict whether someone is likely to comply with their visa conditions) [33].

7. Spain recruits a large proportion of its foreign workers within the framework of nine bilateral agreements, the majority of which are with African and Latin American countries. In 2004, there were an estimated 170 bilateral labour agreements between OECD countries, not all of which were active [34].

8. The General Agreement on Trade in Services (GATS) is a World Trade Organization (WTO) treaty, which came into force in 1995 as a result of the Uruguay Round negotiations. The treaty was created to extend the multilateral trading system to service sector.

9. For example, many of the first bilateral CTLM agreements established by Germany and other European countries with "third countries" were aimed at Eastern Europe. One of the objectives was to legally channel and organize the potential arrival of waves of clandestine workers after the demise of the Soviet Union [18].

10. For example, in the case of the Colombians, "(...) the average wage before the first visit to Spain oscillated between $€ 32$ and $€ 80$ a month, depending on the town of origin, very low when compared with the Columbian minimum wage (€131 in 2006)" [21].

11. Abella [18] has pointed out that these are the two most widely enforced conditions in current programmes, compared with others that have varying levels of effectiveness between programmes and countries.

12. In our study, we heard this argument from some workers, various employers, and also residents in the areas where the UPP is run.

13. The plural nature of bilateral agreements and current Programmes also gives rise to a repertoire of differentiated rights for each group of circular migrants, depending on the Programme.
14. Convention No. 97 aims to regulate migration and protect migrants, defining procedures for both public and private recruitment, assuring nondiscrimination in salaries and benefits, and establishing the right to participate in union activities. Convention No. 143 goes further, calling for the sanctioning of employers who recruit unauthorized workers and those involved in trafficking people, and recommends equal treatment in salaries and other benefits for irregular migrants. The first convention was signed by 42 countries, and the second by only 18 [20].

15. And, importantly, in the eyes of origin states, since they are not considered emigrants.

16. Of course, all of this is framed by the condition of noncitizenry and denizenship [35] that affects immigrants in general, with well-known consequences that have been debated at length.

17. Although this is adjusted to the frameworks of permanent migration, during the time spent in the destination country, all short-term migrants are considered residents.

18. Which does not make a distinction between permanent and temporary migrants [18].

19. As mentioned above, the UPP is based on chain employment, where the majority of workers rotate between various employers; however, this rotation is not decided upon by the workers, but rather by Unió de Pagesos and entrepreneurs together.

20. Despite the establishment of access to residency and, eventually, citizenship being recommended by various authors as "good practice" in this type of programme (see, e.g., [7]).

21. Periods of inactivity do not cost employers, who invoke the established legislation ( 75 per cent minimum of time worked). This is therefore not a problem for employers; it is the workers who directly assume the burden.

22. While workers' representatives are seldom involved in the design and management of CTLM programmes [20].

23. In 2001 the Unió de Pagesos founded Fundació Pagesos Solidaris (the Farmer's Solidarity Foundation), a philanthropic branch responsible for the co-development aspects of the UPP.

24. For more information on the consequences of circular programmes (specifically the UPP), and a critical assessment of the "triple win" result, see Kraft and de Larrard [21]; Mejía [27]; Mejía et al. [36], or Sánchez-Montijano and Faúndez-García [37].

\section{References}

[1] EC, "Communication on 'Circular migration and mobility partnerships between European Union and third countries," 1.9.2005 $\operatorname{COM(2005)} 390$ final, Commission of the European 
Communities, Brussels, Belgium, 2007, http://eur-lex.europa .eu/LexUriServ/LexUriServ.do?uri=COM:2005:0390:FIN:ES: PDF.

[2] S. Castles, "Back to the future? Can Europe meet its labour needs through temporary migration?" International Migration Institute Working Papers 1, International Migration Institute, University of Oxford, Oxford, UK, 2006.

[3] A. Constant and K. Zimmermann, "Circular movements and time away from the host country," IZA Discussion Papers Series 960, IZA-Institute for the Study of Labor, 2003.

[4] P. Fargues, "Circular migration: is it relevant for the South and East of the Mediterranean?" Tech. Rep. 2008/40, European University Institute, Florence, Italy, 2008.

[5] A. Venturini, "Circular migration as an employment strategy for Mediterranean countries," CARIM Analytic and Synthetic Notes 2008/39, 2008.

[6] K. Newland, D. Agunias, and A. Terrazas, Learning by Doing: Experiences of Circular Migration, Migration Policy Group, Washington, DC, USA, 2008.

[7] K. Newland, "Circular migration: a new policy tool for development," in Proceedings of the UNDP-HDR Workshop on "Circular Migration: Recent Research Highlights", September 2008, http://hdr.undp.org/es/informes/mundial/idh2009/ seminarios/title,13303,es.html.

[8] UNESCO, People on the Move: Handbook of Selected Terms and Concepts, Version 1.0, THP Foundation-UNESCO, The Hague, The Netherlands, 2008.

[9] GCIM, "Migration in an interconnected world: new directions for action," Tech. Rep., Global Commission on International Migration, Geneva, Switzerland, 2005, http://www.unhcr.org/ refworld/docid/435f81814.html.

[10] International Organization for Migration (IOM), Handbook on Establishing Effective Labour Migration Policies in Countries of Origin and Destination, OSCE, IOM, ILO, Vienna, Austria, 2006.

[11] EC, "Communication 'Migration and development: some concrete orientations'” 16.5.2007 COM(2007) 248 final, Commission of the European Communities, Brussels, Belgium, 2005, http://eur-lex.europa.eu/LexUriServ/LexUriServ .do?uri=COM:2007:0248:FIN:ES:PDF.

[12] OECD, Policy Coherence for Development: Migration and Developing Countries, A Development Centre Perspective, OECD, Paris, France, 2007.

[13] V. Gonzálvez Pérez, "La inmigración irregular de africanos en España, balances y perspectivas," Investigaciones Geográficas, vol. 23, pp. 47-57, 2000.

[14] V. Gozálvez Pérez, "Inmigrantes marroquíes y senegaleses en la España del mediterráneo,” Tech. Rep. 440, Generalitat de Valencia, Conselleria de Treball i Afers Socials, 1995.

[15] R. Aguilera, "El acceso de los inmigrantes irregulares al mercado de trabajo: los procesos de regularización extraordinaria y el arraigo social y laboral," Revista del Ministerio de Trabajo y Asuntos Sociales, vol. 63, pp. 175-195, 2006.

[16] S. Gil Araujo, "Nation-state building process and cultural diversity: Spain," in Nation-State Building Processes and Cultural Diversity, J. Blaschke, Ed., Parabolis, Berlin, Germany, 2005.

[17] GFMD, "Human capital development and labor mobility: maximizing opportunities and minimizing risks," Background Paper for Roundtable 1, session 1.2, Global Forum on Migration and Development, Brussels, Belgium, 2007, Temporary labor migration as a contribution to development: sharing responsibility, http://www.gfmd-fmmd.org/en/system/files/Background+Paper+Session+1.2+EN.pdf.
[18] M. Abella, "Policies and best practices for management of temporary migration," in Proceedings of the International Symposium on International Migration and Development, UN/ POP/MIG/SYMP/2006/03, United Nations, Turin, Italy, 2006.

[19] K. Newland, Can Migrants, Countries of Origin and Countries of Destination All Win from Circular Migration? Global Forum on Migration and Development, Brussels, Belgium, 2007.

[20] P. Martin, Managing Labor Migration: Temporary Worker Programmes for the 21st Century, International Institute for Labour Studies, ILO, Geneva, Switzerland, 2006.

[21] R. Kraft and M. de Larrard, Codesarrollo y migraciones laborales internacionales: Evaluación de los Programmeas de migración temporal y circular entre Colombia y España [M.S. thesis], University of Sciences-Po, Paris, France, 2007.

[22] M. Ruhs, "The potential of temporary migration programmes in future international migration policy," Tech. Rep., Policy Analysis and Research Programme, Global Commission on International Migration, 2005.

[23] D. Agunias and K. Newland, Circular Migration and Development: Trends, Policy Routes, and Ways Forward, Migration Policy Group, Brussels, Belgium, 2007.

[24] EMN, Temporary and Circular Migration: Empirical Evidence, Current Policy Practice and Future Options in EU Member States, European Migration Network, European Union, Brussels, Belgium, 2011.

[25] A. Pécoud, "The UN convention on migrant workers rights and international migration management," Global Society, vol. 23, no. 3, pp. 333-350, 2009.

[26] International Organization for Migration (IOM), Glossary on Migration, International Organization for Migration (IOM), Geneva, Switzerland, 2004.

[27] W. Mejía, "Contratación laboral en origen en Colombia: Mirada a dos Programmeas de temporeros," in Seminario Por una Migración Reglada, Normalizada y Regulada: Contratación en Origen. Vías legales para la Lucha Contra el Tráfico Humano Laboral, AICODE/SENA/COLOMBIA NOS UNE, Bogotá, Colombia, 2008.

[28] R. Holzmann, J. Koettl, and T. Chernetsky, "Portability regimes of pension and health care benefits for international migrants: an analysis of issues and good practices," Social Protection Discussion Paper Series 519, World Bank, 2005.

[29] International Organization for Migration (IOM), "Segunda Evaluación Programa Trabajadores(as) Agrícolas a Canadá," Cuaderno de Trabajo Sobre Migración 25, IOM, Ciudad de Guatemala, República de Guatemala, 2008.

[30] M. Ruhs, "Migrant rights, immigration policy and human development," Human Development Research Paper 23, United Nations Development Programme, 2009.

[31] R. Zapata-Barrero, R. Faúndez-Garcia, and E. Sánchez-Montijano, "Temporary and circular labour migration (TCLM) of workers between Colombia and Spain: a model to consolidate," in Temporary and Circular Labour Migration Experiences, Challenges and Opportunities, vol. 2 of IOM Series of Research into Migration, pp. 48-76, 2009.

[32] A. Portes and W. Haller, "The informal economy," in The Handbook of Economic Sociology, N. Smelser and R. Swedberg, Eds., Princeton University Press, Princeton, NJ, USA, 2nd edition, 2005.

[33] Home Office, A Points-Based System: Making Migration Work for Britain, vol. 6741, Home Office, London, UK, 2006.

[34] OECD, Migration for Employment-Bilateral Agreements at a Crossroads, OECD, Paris, France, 2004. 
[35] T. Hammar, Democracy and the Nation State: Aliens, Denizens and Citizens in a World of International Migration, Avebury, Gower, Aldershot, UK, 1990.

[36] W. Mejía et al., Working Model Findings Relative to Recruitment in Colombia of Workers for Temporary and Circular Migration by the Farmer's Union of Cataluña: View from the Workers' Community of Origin, Research Group on Human Mobility, Network of Public Universities of the Coffee Region, ALMA MATER, Pereira, Colombia, 2008.

[37] E. Sánchez-Montijano and R. Faúndez-García, "Migración Laboral Temporal y Circular y Codesarrollo: estudio de caso de una articulación possible," Migraciones, vol. 30, pp. 43-70, 2012. 


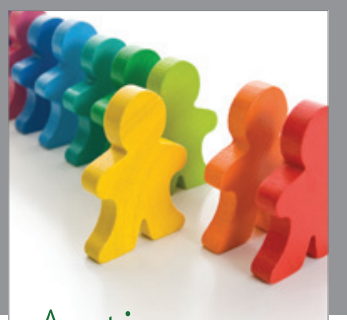

Autism

Research and Treatment
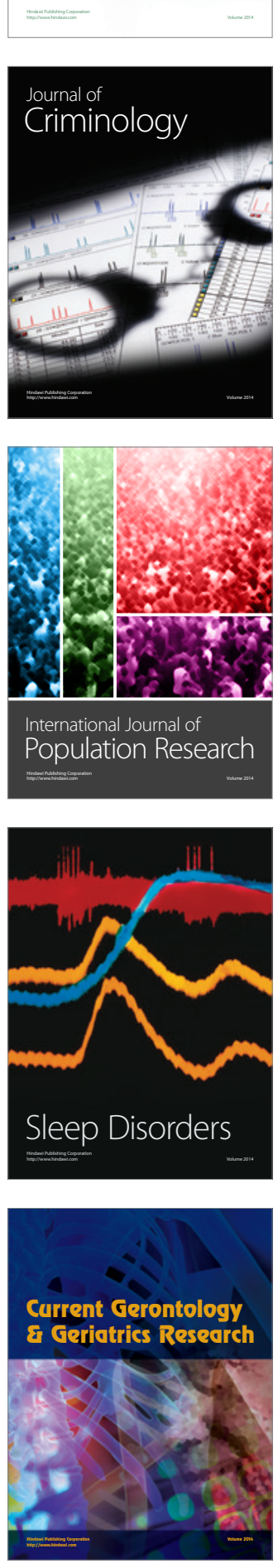
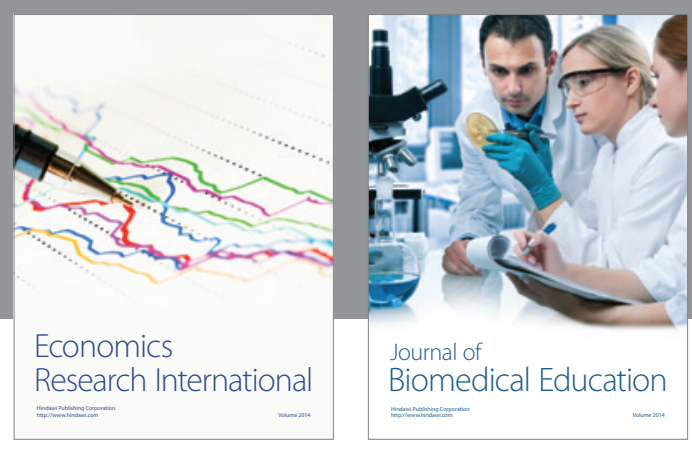

Journal of

Biomedical Education

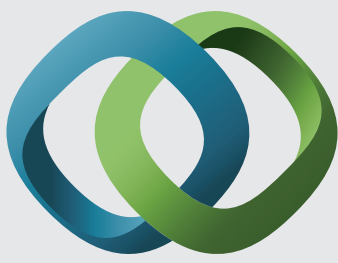

\section{Hindawi}

Submit your manuscripts at

http://www.hindawi.com
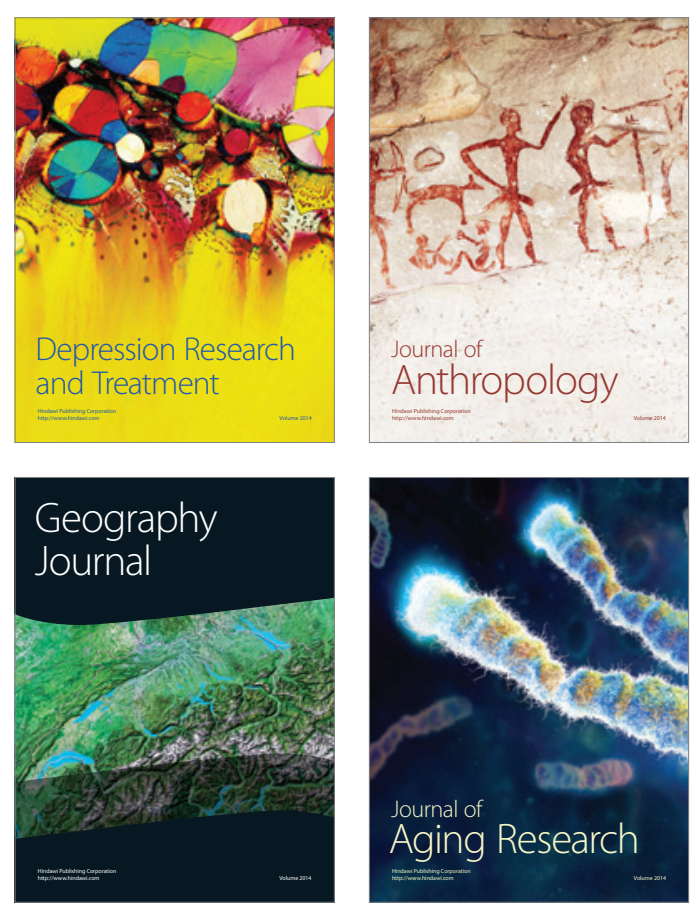

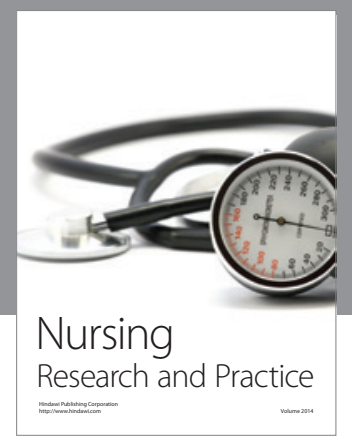

Nursing

Research and Practice

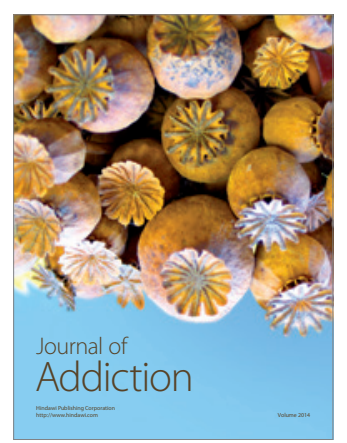

Child Development

Research

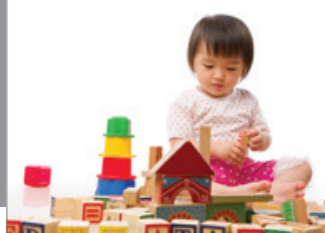

迥
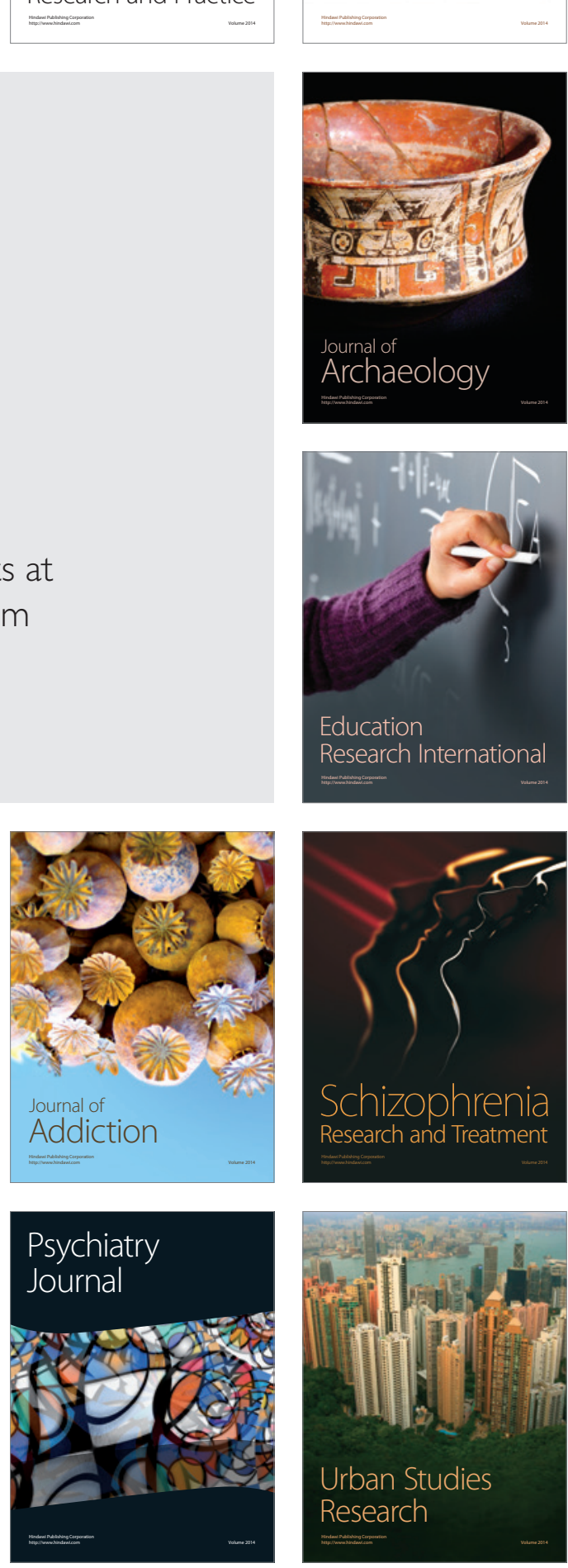